\title{
EFEKTIVITAS EDUKASI FISIOTERAPIS TERHADAP KETERAMPILAN PEMECAHAN MASALAH BELAJAR MAHASISWA UNIVERSITAS WIDYA DHARMA KLATEN
}

\author{
Zuyina Luklukaningsih \\ Jurusan Psikologi ; Universitas Widya Dharma Klaten \\ Jl. Ki Hajar Dewantoro ; Macanan ; Karanganom ; Klaten Utara ; Klaten
}

\begin{abstract}
Abstrak
Strategi pemecahan masalah belajar sangat diperlukan khususnya bagi mahasiswa, sehingga dapat meningkatkan potensial nilai akademik. Penelitian ini bertujuan untuk memberikan pemahaman strategi pemecahan masalah belajar. Terdapat dua kelompok yang dipilih secara random yaitu kelompok sebelum edukasi dan kelompok setelah diberi edukasi keterampilan pemecahan masalah. Penelitian ini diujicobakan pada mahasiswa Universitas Widya Dharma Klaten sejumlah 7 mahasiswa, terdiri dari 2 mahasiswa perempuan dan 5 mahasiswa laki laki. Analisis data yang digunakan yaitu analisis inferensial dengan uji Wilcoxon. Hasil analisis data menunjukkan P.sig<Alpha atau $0.000<0.05$ sehingga dapat disimpulkan bahwa ada perbedaan keterampilan sebelum pemberian edukasi dengan setelah diberikan edukasi keterampilan pemecahan masalah. P-value yaitu Asymp. Sig. (2-tailed) pada hasil pretest 0.997 dan postest 0.955 keterampilan menyelesaikan masalah. Hasil yang diperoleh terdapat perbedaan keterampilan sebelum pemberian edukasi dengan setelah diberikan edukasi dan dapat dikatakan bahwa pemberian edukasi fisioterapis efektif terhadap keterampilan problem solving belajar mahasiswa. Hasil ini mengindikasikan bahwa pemberian edukasi fisioterapis efektif meningkatakan kemampuan mahasiswa dalam menyelesaikan kesulitan belajarnya.
\end{abstract}

Kata kunci: Keterampilan pemecahan masalah; Masalah belajar; Efektifitas edukasi fisioterapis

\begin{abstract}
[EFFECTIVENESS PHYSIOTHERAPIS OF EDUCATION TOWARDS SKILLS TO SOLVE STUDENT PROBLEMS WIDYA DHARMA KLATEN UNIVERSITY] Learning problem solving strategies are needed especially for students, so they can increase the potential of academic values. This study aims to provide an understanding of learning problem solving strategies. There were two groups chosen randomly, namely the group before education and the group after being educated on problem solving skills. This research was tested on 7 Widya Dharma University students in Klaten, consisting of 2 female students and 5 male students. Data analysis used was inferential analysis with the Wilcoxon test. The results of data analysis showed P.sig <Alpha or $0,000<0.05$ so that it can be concluded that there were differences in skills before giving education with education after problem solving skills were given. P-value is Asymp. Sig. (2-tailed) on the results of pretest 0.997 and post- 0.955 problem solving skills. The results obtained there are differences in skills before giving education with after being given education and it can be said that the education of physiotherapists is effective against the problem solving skills of student learning. These results indicate that providing effective physiotherapist education increases the ability of students to solve their learning difficulties.
\end{abstract}

Keywords: Problem solving skills; Learning problem; Effectiveness of educational physiotherapists

\section{Pendahuluan}

Semua mahasiswa pada prinsipnya mempunyai keinginan untuk meraih prestasi akademik yang gemilang. Keadaan yang jauh

\footnotetext{
*) Zuyina Luklukaningsih

E-mail: lukluk2201@gmail.com
}

dari persoalan yang dapat mengganggu aktivitas pembelajaran. Ketika individu berkeputusan untuk melanjutkan studi, individu mendambakan situasi akademis yang lancar. Meraih Indeks prestasi akademis yang 
memuaskan merupakan tujuan yang ingin dicapai mahasiswa. Setiap mahasiswa yang serius dan meniatkan diri untuk studi, mahasiswa tersebut berusaha menyingkirkan hambatan dalam belajar. Ada beberapa cara yang ditempuh, misalnya dengan berbagi semangat dengan teman, bertanya pada dosen apabila menjumpai materi belajar yang belum dimengerti.

Mulyati (2007) mengatakan kemampuan penyelesaian persoalan ialah meminimalkan dampak negatif sedikit mungkin. Keterampilan penyesaian persoalan yang tidak terlaksana maka dampaknya adalah masalah tidak kunjung selesai. Dampak lain yang ditimbulkan dari tidak tercapainya penyelesaian masalah ini ialah ketidaknyamanan. Kondisi tidak nyaman ini terjadi baik pada individu itu sendiri maupun individu lain yang ada disekitarnya. Pola komunikasi memiliki peranan penting dalam penyelesaian persoalan masalah. Individu yang dapat menyampaikan pesan dengan baik. akan dapat menyelesaikan persoalan dengan baik pula. Sebaliknya, individu yang tidak memiliki kemampuan berkomunikasi, maka akan terhimpit berbagai persoalan dalam belajar.

Rational Problem Solving merupakan suatu bentuk keterampilan pemecahan masalah yang konstruktif. Misalnya ditempuh dengan cara berunding serta mengambil langkah sistematik dalam kemampuan memecahkan permasalahan. Cara ini terdiri dari 3 tahapan, meliputi : (1) Identifikasi permasalahan, yaitu memahami persoalan yang dihadapi dengan menelaah banyak spesifikasi dan fakta mengenai kemungkinan munculnya rintangan dan tujuan yang logis dalam menyelesaikan persoalan; (2) Menentukan jalan keluar alternatif, yaitu selain identifikasi masalah harus mencari jalan keluar pilihan yang lain. Fokus pada tujuan untuk memecahkan persoalan tersebut dan mencoba untuk mengidentifikasi banyak solusi yang memungkinkan. Dapat juga ditempuh solusi yang bersifat sederhana; (3) Mengambil Keputusan, yaitu individu mengantisipasi terhadap keputusannya dengan jalan keluar yang berbeda, berusaha untuk mempertimbangkan dan membandingkan kemudian memilih yang terbaik atau solusi yang efektif yang paling berpotensi. Sehingga keputusan yang di ambil adalah keputusan yang tepat.
Mengabaikan kata hati merupakan salah satu pola karakteristik penyelesaian masalah yang disfungsional. Hal ini tidak terdapat usaha aktif yang digunakan dalam strategi menyelesaikan masalah. Teknisnya, usaha ini menyempit, berhati-hati, sangat cepat, dan tidak lengkap. Problem solver mengesampingkan dan mengabaikan kata hati.

Salah satu karakteristik penyelesaian masalah yang disfungsional berupa penundaan, pasif atau tidak melakukan apapun terhadap permasalahan yang di hadapi. Terkesan bahwa individu tersebut lari dari kenyataan. Kondisi ini terdapat unsur ketergantungan pada pihak lain dalam memecahkan masalah. Individu tersebut berharap ada pihak lain yang menggantikan posisinya dan mencari penyelesaian dari permasalahan yang ada. Ada kecenderungan menjauh dari permasalahan yang sedang di hadapi. Terlihat kesan ada penundaan terhadap langkah penyelesaian masalah. Tidak mempedulikan berbagai permasalahan yang sedang digeluti, tampak jelas ada upaya untuk menghindar dari persoalan yang seharusnya dipecahkan. Individu tersebut berdiam diri, tidak ada langkah apapun yang di ambil.

\section{Metode}

Penelitian ini merupakan penelitian eksperimen semu (kuasi eksperimental). Penelitian eksperimen merupakan aktivitas percobaan yang mempunyai tujuan untuk mengetahui dampak yang muncul sebagai akibat dari perlakuan tertentu. Ada dua kelompok yang dipilih secara acak. Tahapan yang dilalui ada 2 cara. Tahap pertama sebelum dilakukan edukasi keterampilan penyelesaian masalah dan tahap ke dua setelah diberi edukasi keterampilan pemecahan masalah. Penelitian ini dilakukan dengan memberikan skala keterampilan pemecahan masalah kepada responden. Durasi yang diberikan untuk menjawab pertanyaan dalam bentuk skala keterampilan pemecahan masalah sama, artinya sebelum dan sesudah diberikan edukasi oleh seorang Fisioterapis. Simbol desain dalam penelitian adalah sebagai berikut :

Pengukuran $(\mathrm{O} 1) \rightarrow$ Treatment $\rightarrow$ Pengukuran $(\mathrm{O} 2)$

Gambar 1. Desain Penelitian 
Tabel 3. Descriptive Statistics

\begin{tabular}{lllr}
\multicolumn{1}{c}{ Pen } & & $\mathrm{N}$ & Minim \\
\cline { 2 - 3 } garuh & & & \\
edukasi & yang dilakukan & oleh & seorang \\
fisoterapis. Terdapat adanya & perbedaan skor \\
keterampilam pemecahan masalah belajar pada \\
saat pretest dibandingkan dengan skor \\
keterampilan pemecahan masalah belajar pada \\
saat post test.
\end{tabular}

\section{Hasil dan Pembahasan}

Subyek penelitian adalah mahasiswa Universitas Widya Dharma Klaten, program studi Fisioterapi. Jumlah subyek sebanyak 7 orang yang terdiri dari 5 orang mahasiswa lakilaki dan 2 orang mahasiswa perempuan.

Sesuai Tabel 1 diatas tampak terpapar bahwa jumlah subyek keseluruhan adalah 7 mahasiswa. Responden dengan jenis kelamin laki-laki sebanyak 2 orang (30\%) dan responden berjenis kelamin perempuan sebanyak 5 orang $(70 \%)$.

\begin{tabular}{|c|c|c|c|c|}
\hline \multicolumn{2}{|c|}{ Maximum } & Mean & Std. Deviation & \\
\hline \multicolumn{5}{|c|}{$\begin{array}{c}\text { Distribusi Frekeuensi Responden berdasarkan } \\
\text { Jenis Kelamin }\end{array}$} \\
\hline No & \multicolumn{2}{|c|}{ Jenis Kelamin } & Jumlah & Frekeuensi \\
\hline 1 & \multicolumn{2}{|c|}{ Laki-laki } & 2 & $30 \%$ \\
\hline \multirow[t]{2}{*}{2} & \multicolumn{2}{|c|}{ Perempuan } & 5 & $70 \%$ \\
\hline & \multicolumn{2}{|r|}{ Total } & 7 & $100 \%$ \\
\hline
\end{tabular}

\section{Uji Asumsi Normalitas}

Uji ini bertujuan untuk mendapatkan informasi apakah data yang diteliti yaitu keterampilan penyelesaian masalah belajar penyebarannya berdistribusi normal atau tidak. Uji normalitas dalam penelitian ini dilakukan dengan menggunakan uji one sample Kolmogorov - Smirnov Test. Normalitas data akan terpenuhi jika probabilitas atau $\mathrm{p}>0,05$. Berdasarkan analisis didapatkan rangkuman hasil sebagai berikut:

Tabel 2. Hasil Uji Normalitas

One-Sample Kolmogorov-Smirnov Test

\begin{tabular}{|c|c|c|c|}
\hline & & Pretest & Posttest \\
\hline $\mathrm{N}$ & & 7 & 7 \\
\hline \multirow[t]{2}{*}{ Normal Parametersa } & Mean & 1.4372 & 1.594 \\
\hline & Std. Deviation & 3.4503 & 1.105 \\
\hline \multirow{3}{*}{$\begin{array}{l}\text { Most Extreme } \\
\text { Differences }\end{array}$} & Absolute & .153 & .194 \\
\hline & Positive & .153 & .194 \\
\hline & Negative & -.141 & -.158 \\
\hline \multicolumn{2}{|l|}{ Kolmogorov-Smirnov Z } & .406 & .512 \\
\hline \multicolumn{2}{|l|}{ Asymp. Sig. (2-tailed) } & .997 & .955 \\
\hline \multicolumn{4}{|c|}{ a. Test distribution is Normal. } \\
\hline
\end{tabular}

Berdasarkan Tabel 3 hasil komputasi dapat

Tabel 2 di atas menunjukkan nilai P-value yaitu Asymp. Sig. (2-tailed) pada hasil pretest 0.997 dan postest 0.955 keterampilan menyelesaikan masalah. Oleh karena Asymp. Sig. (2-tailed) ) P > 0,05), maka dapat disimpulkan bahwa residual telah memenuhi asumsi distribusi normal.

\section{Analisis Deskriptif}

Analisis deskriptif dengan menggunakan SPSS 21 for windows telah menunjukkan skor minimum, skor tertinggi, mean, dan standar deviasi dari masing-masing variabel keterampilan menyelesaikan masalah. dilihat bahwa hasil analisis deskriptif data empirik terendah untuk pretest adalah 140 dan skor tertinggi adalah 149 , dengan nilai rata-rata sebesar 143 serta standar deviasi sebanyak 3.450. Sedangkan hasil analisis deskriptif data empirik terendah untuk post test adalah 143 dan skor tertinggi adalah 175, dengan nilai rata-rata sebesar 159 serta standar deviasi sebanyak 11.058. Berdasarkan data tabel di atas terjadi peningkatan nilai rata-rata keterampilan menyelesaikan masalah belajar pada mahasiswa Widya Dharma Klaten. 


\begin{tabular}{crrrrr} 
Pretest & 7 & 140.0 & 149.00 & 143.7 & 3.450 \\
\hline Posttest & 7 & 143.0 & \multirow{2}{*}{175.00} & 159.4 & 11.058 \\
& 7 & 0 & & & \\
\hline $\begin{array}{l}\text { Valid N } \\
\text { (listwise) }\end{array}$ & 7 & & & & \\
\hline
\end{tabular}

\section{Hasil uji hipotesis}

Hipotesis dalam penelitian ini ialah efektifitas edukasi fisioterapis terhadap keterampilan penyelesan masalah belajar. Untuk pengujian hipotesis maka akan dilakukan analisis dengan menggunakan Wilcoxon Match
Pairs Test dengan membandingkan skor pre dan post test menggunakan SPSS 21 for windows. Hasil uji hipotesis dapat dilihat pada tabel berikut:

Tabel 4. Hasil uji hipotesis dengan Wilcoxon

\begin{tabular}{c}
\hline Z \\
\hline Asymp. Sig. (2-tailed) \\
\hline a. Based on negative ranks. \\
b. Wilcoxon Signed Ranks Test
\end{tabular}

Hasil uji hipotesis menunjukkan bahwa probabilitas (Asymp.Sig) <0,05 maka Ho ditolak dan Ha diterima. Sedangkan jika probabilitas (Asymp.Sig) > 0,05 maka Ho diterima dan Ha ditolak. Pada tabel 4.4 dapat dilihat bahwa Asymp. Sig. Sebesar 0,018 sehingga 0,018 <0,05 sehingga Ho pada penelitian ini di tolak dan Ha diterima, sehingga edukasi fisioterapis efektif terhadap keterampilan menyelesaikan masalah belajar pada mahasiswa. Dengan demikian ada efektivitas yang signifikan edukasi fisioterapi terhadap keterampilan pemecahan masalah belajar mahasiswa. Perlakukan terhadap kelompok eksperimen berhasil meningkatkan kemampuan mahasiswa dalam menyelesaikan masalah belajar.

\section{Pembahasan}

Setiap mahasiswa pada dasarnya sangat menginginkan pencapaian prestasi akademik yang memuaskan. Sebuah kondisi yang jauh dari permasalahan yang dapat mengganggu proses pembelajaran yang muncul dalam rentang masa belajar mahasiswa antara lain kondisi psikologis ketika belajar, kejenuhan dalam belajar, tidak merasa senang dengan materi yang dipelajari, tidak mengetahui manfaat yang dipelajari, dosen yang kurang menyenangkan dalam menyampaikan materi, mahasiswa kurang mengetahui manfaat dari materi yang dipelajari.

Penelitian ini merupakan penelitian eksperimen semu. Penelitian ini mempunyai maksud untuk meramalkan hal-hal yang terjadi. Rancangan penelitian eksperimen dilaksanakan pada kondisi yang memungkinkan semua variabel yang relevan Danim (2013). Tahap awal sebelum dilakukan edukasi penyelesaian masalah dan tahap ke dua, setelah dilakukan edukasi keterampilan pemecahan masalah. Penelitian ini dilakukan dengan memberikan skala keterampilan pemecahan masalah kepada responden. Penelitian ini diujicobakan pada mahasiswa Widya Dharma Klaten sejumlah 7 mahasiswa, terdiri dari 2 mahasiswa perempuan dan 5 mahasiswa laki laki. Sumber data yang di gunakan adalah model skala yang memuat pertanyaan keterampilan pemecahan masalah belajar. P-value yaitu Asymp. Sig. (2tailed) pada hasil pretest 0.997 dan post test 0.955 keterampilan menyelesaikan masalah. Oleh karena Asymp. Sig. (2-tailed) ) P > 0,05), analisis deskriptif data empirik terendah untuk pre test adalah 140 dan skor tertinggi adalah 149, dengan nilai rata-rata sebesar 143 serta standar deviasi sebanyak 3.450. Sedangkan hasil analisis deskriptif data empirik terendah untuk post test adalah 143 dan skor tertinggi adalah 175, dengan nilai rata-rata sebesar 159 serta standar deviasi sebanyak 11.058. Sehingga terjadi peningkatan nilai rata-rata keterampilan 
menyelesaikan masalah belajar pada mahasiswa Widya Dharma Klaten.

Analisis data yang digunakan adalah analisis inferensial. Uji hipotesis yang dipakai adalah uji Wilcoxon. Hasil analisis data menunjukkan P.sig<Alpha atau $0.000<0.05$ sehingga ada perbedaan keterampilan sebelum pemberian edukasi dengan setelah diberikan edukasi. Pemberian edukasi fisioterapis efektif terhadap keterampilan pemecahan masalah belajar mahasiswa.

Berdasarkan hasil penelitian, dapat disimpulkan bahwa pemberian edukasi yang dilakukan oleh seorang fisioterapis memberikan pengaruh terhadap keterampilan pemecahan masalah belajar. Mahasiswa yang mendapatkan edukasi berupa pemahaman mengenai strategi pemecahan masalah belajar akan menunjukkan mahasiswa tersebut mempunyai kemampuan untuk menyelesaikan masalah belajar, Sebaliknya mahasiswa yang belum mendapatkan edukasi berupa pemahaman strategi pemecahan masalah belajar, maka mahasiswa tersebut akan mengalami kendala dalam memecahkan masalah belajar.

Instrumen penelitian merupakan alat yang di gunakan peneliti untuk mempermudah pekerjaan dalam mengumpulkan data penelitian, instrumen penelitian yang digunakan dalam penelitian ini adalah: observasi dan tes. Selain itu, instrumen penelitian haruslah dirancang dan disusun sebelum dilaksanakannya pembelajaran. Berkenaan dengan perencanaan, Mulyasa (2008) mengemukakan bahwa proses pembelajaran yang dimulai dengan fase pengembangan rencana pelaksanaan pembelajaran. Pada saat metodologi telah diidentifikasi, akan membentu dosen dalam mengorganisasikan materi perkuliahan sesuai dengan kurikulum.

Efektivitas dapat diartikan sampai dimana tercapainya suatu tujuan yang sudah ditentukan. Kata efektivitas lebih mengacu pada out put yang telah menjadi target. Efektivitas sangat penting dalam pembelajaran karena berhubungan dengan tindakan keberhasilan mahasiswa. Dalam penelitian ini, hasil yang didapat adalah nilai P.sig<Alpha atau $0.000<0.05$ sehingga ada perbedaan keterampilan sebelum pemberian edukasi dengan setelah diberikan edukasi dan dapat dikatakan pemberian edukasi fisioterapi efektif terhadap keterampilan problem solving belajar mahasiswa. Dari hasil uji statistik juga diketahui bahwa keterampilan pemecahan masalah belajar mahasiswa lebih baik setelah diberikan perlakuan dalam bentuk edukasi fisioterapi.

Dapat menemukan berbagai alternatif cara menyelesaikan masalah, hingga mampu mengaitkan materi dengan konstruk yang ada di sekitarnya. Berbagai kegiatan tersebut pada akhirnya dapat meningkatkan/ memperbaiki prestasi dan keterampilan berpikir kritis mahasiswa. Pengalaman belajar yang didapat mahasiswa dari proses penyelesaian masalah akan memberikan penambahan wacana secara akademis. Dengan demikian, tercipta lingkungan pembelajaran yang positif di kelas sehingga kemampuan yang dimiliki individu dapat diterapkan dalam menyelesaikan masalah. Karagedika (2015) mengemukakan dan meyakini bahwa keterampilan penyelesaian masalah dapat diperoleh dari kritikan dan masukan yang bersifat membangun. Pemberian edukasi dapat membantu mahasiswa untuk meningkatkan/memperbaiki keterampilan berpikir kritis mahasiswa untuk menyelesaikan masalah persoalan belajar.

Secara keseluruhan skor kemampuan menyelesaikan masalah belajar mahasiswa pada kelompok eksperimen lebih besar dibandingkan dengan kelompok kontrol. Hasil ini menunjukan bahwa pemberian edukasi fisioterapi efektif meningkatkan kemampuan mahasiswa dalam menyelesaikan kesulitan belajarnya.

\section{Simpulan dan Saran}

Berdasarkan hasil penelitian mengenai "Efektivitas Edukasi Fisioterapis terhadap Ketrampilan Pemecahan Masalah Belajar Mahasiswa", diperoleh kesimpulan bahwa terdapat perbedaan nilai statistik antara kelompok pre test (sebelum diberikan edukasi) dengan kelompok post test (setelah diberikan edukasi) sehingga dapat dikatakan bahwa pemberian edukasi fisioterapi efektif terhadap keterampilan pemecahan masalah belajar mahasiswa. Sehingga diharapkan pemberian edukasi fisioterapi dapat diterapkan pada mahasiswa yang nantinya dapat meningkatkan kemampuan mahasiswa dalam menyelesaikan kesulitan belajarnya.

\section{Ucapan Terima Kasih}

Terima kasih disampaikan kepada 
Universitas Widya Dharma Klaten yang telah mendukung terlaksananya kegiatan pengabdian kepada masyarakat ini dan beberapa pihak lain yang terlibat.

\section{Daftar Pustaka}

Azwar, S. (2008). Sikap manusia. Teori dan pengukurannya. Edisi ke 2. Cetakan XII. Yogyakarta: Pustaka Pelajar.

Baumeister, R. F., \& Vohs, K. D. (2002). The pursuit of meaningfulness in life. Handbook of positif psychology (pp.608-628). New York: Oxford University Press.

Brits. (2000). Plobem Solving In Early Childhood Classrooms. Eric digest. Clearing House on Elementary and Early Childhood Education University Of Illinois. Urbana_champaign. Diambil

Http://www.ericps.ed.uiuc.edu/eece/index Html.

DJarwanto, P. (2003). Statistik Induktif. Yogyakarta: BPFE-UGM.

Gulo, W. (2002). Strategi belajar mengajar. Jakarta: Grasindo.

Ifanali. (2014). Penerapan langkah-langkah polya untuk meningkatkan kemampuan pemecahan masalah soal cerita pecahan pada siswa Kelas VII SMP Negeri 13 Palu. Jurnal Elektronik Pendidikan Matematika Tadulako , 147-158.

King, L. (2010). Psikologi umum. Jakarta: Salemba Humanika.

Mahrita \& Mulyati, R. (2007). Hubungan pola asuh demokratis orang tua dengan kemampuan pemecahan masalah (problem solving ) pada remaja. (Naskah Publikasi). Rogram Studi Psikologi Fakultas Psikologi Dan Ilmu Sosial Budaya Universitas Islam Indonesia Yogy.

Mu'qodin, Z. (2002). Mengenal kecerdasan emosional remaja. Bandung : Kaifa.
Sugiyono. (2011). Metode penelitian kuantitatif, kualitatif dan $R \mathcal{E} D$. Bandung: Alfabeta.

Taylor, S. P. (2009). Psikologi sosial Edisi 12. Jakarta: : Kencana Prenada Media Group.

Mu'qodin, Z. (2002). Mengenal kecerdasan emosional remaja. Bandung : Kaifa.

Abidin, Z. (2007). Analisis eksistensial. Jakarta: Raja GrafindoPersada

Ahmadi, A. (1998). Psikologi sosial. Bandung: Mizan.

Arikunto, S. (2006). Prosedur penelitian. Suatu pendekatan praktik. Edisi Revisi VI. Cetakan XIII. Jakarta: RinekaCipta.

Azwar, S. (1998). Metode penelitian. Yogyakarta: PustakaPelajar.

Bailey, R.W. (1989). Human performance engineering. New Jersey

Newcomb, TM., Turner, RH. \& Converse, PE. (1978). Psikologi sosial. Bandung: Diponegoro.

Walgito, B. (2003). Psikologi sosial ,suatu pengantar. Yogyakarta: Andi Offset.

Watson, D.L. (2002). Self directed behavior. California: Brooks Press.

Wibowo, I. (2009). Psikologi sosial. Tim Penulis Fakultas Psikologi UI. Jakarta: Penerbit Salemba Humanika. (penyunting: SaelitoWirawan).

Arikunto, S. (2006). Prosedur penelitian. suatu pendekatan praktik. Edisi Revisi VI. Cetakan XIII. Jakarta: Rineka Cipta.

Notoatmodjo, S. (2005). Pendidikan dan perilaku kesehatan. Jakarta: Rineksa Cipta.

Lubis, Y.U. (2005). Kelola konflik dengan cantik. dalam http://www.eramuslim.com.

Schultz, D. (1991). Psikologi pertumbuhan, modelmodel kepribadian sehat. Yogyakarta: Kanisius. 